\title{
Heterotrophic bacterial mediation of ammonium and dissolved free amino acid fluxes in the Mississippi River plume
}

\author{
James B. Cotner $\mathrm{Jr}^{1,2,}$, Wayne S. Gardner ${ }^{2}$ \\ ${ }^{1}$ Cooperative Institute for Limnology and Ecosystem Research, \\ ${ }^{2}$ NOAA Great Lakes Environmental Research Laboratory, 2205 Commonwealth Blvd., Ann Arbor, Michigan 48105, USA
}

\begin{abstract}
Bacterial nitrogen regeneration processes are an important source of nitrogen in the most productive regions of the Mississippi River plume (Gulf of Mexico). We examined bacterial growth rates, ammonium regeneration rates, and labile dissolved organic carbon/nitrogen fluxes on 2 cruises in the Mississippi River plume. In summer, surface water bacterial production rates, ammonium regeneration rates, and amino acid turnover rates were higher at intermediate salinities than corresponding rates at the river mouth or in high salinity waters. In winter, surface amino acid turnover rates were highest in the river but growth rates were highest in the plume and ammonium regeneration rates were similar at all sites. Regeneration rates in the plume were an order of magnitude greater in the summer than in the winter. A significant proportion of the bacterial nitrogen demand may be provided by amino acid fluxes in summer, especially in the plume. Measurements of $\mathrm{NH}_{4}$ regeneration after manipulating bacterial abundances suggest that heterotrophic bacteria contributed a variable proportion ( 7 to $50 \%$ ) of total N-regeneration in summer and that dissolved free amino acids could be a major substrate for ammonium regeneration. Depth profiles, spatial distributions, and seasonal differences in ammonium regeneration rates imply that the fastest regeneration rates occur spatially and temporally where primary production is the greatest.
\end{abstract}

\section{INTRODUCTION}

The Mississippi River plume supports one of the most productive fisheries in the United States. In recent years, the extent of hypoxia has increased and threatens the productivity of nearshore fisheries. Increased nutrient inputs from the Mississippi River have been identified as an important factor in the increased development of hypoxia in this region (Turner \& Rabalais 1991).

While increased nutrient input is apparently the controlling factor in hypoxia development, many biological processes regulate allocation of nutrients to different trophic levels in the food web and fluxes to bottom waters. As much as $60 \%$ of total primary production

\footnotetext{
- Present address: Department of Wildlife and Fisheries Sciences, Texas A\&M University, College Station, Texas 77845-2258, USA
}

passes through heterotrophic bacteria (Ducklow 1983, Cole et al. 1988). Heterotrophic bacterial processes can regulate particle transport to bottom waters by metabolizing dissolved and particulate organic carbon and can also help regulate productivity by remineralizing nitrogen from dissolved organic nitrogen compounds (DON).

Dissolved free amino acids (DFAA) are important components in the cycling of both carbon and nitrogen in marine systems (Jorgensen \& Sondergaard 1984, Fuhrman 1990). Although total concentrations in seawater are usually less than $500 \mathrm{nM}$, dissolved free amino acid pools turn over rapidly and are major substrates fueling bacterial growth (Coffin 1989, Fuhrman 1990)

In this study, we examined bacterial growth, nitrogen mineralization rates, and dissolved amino acid cycling in the Mississippi River plume and Gulf shelf. Specifically, we attempted to answer 2 questions: 
(1) What proportion of the total community $\mathrm{NH}_{4}$ regeneration rate is facilitated by heterotrophic bacteria in the Mississippi River plume? (2) Does labile dissolved organic nitrogen (DON) availability regulate the heterotrophic bacterial role in $\mathrm{NH}_{4}$ regeneration? Both questions were addressed spatially and temporally (winter and summer) in the plume.

\section{MATERIALS AND METHODS}

Study site. Studies were performed in the northern Gulf of Mexico on 2 cruises aboard either the RV 'Malcolm Baldrige' (February 1991) or 'Pelican' (September 1991). Sampling efforts were focused over a salinity gradient from the Southwest Pass $\left(28^{\circ} 44.75^{\prime} \mathrm{N}\right.$, $\left.89^{\circ} 21.14^{\prime} \mathrm{W}\right)$ to blue water stations in the gulf $\left(27^{\circ}\right.$ $51.83^{\prime} \mathrm{N}, 90^{\circ} 01.44^{\prime} \mathrm{W}$ ). Surface samples were collected with either a clean plastic bucket or Niskin bottles mounted on a rosette sampler (General Oceanics) equipped with either a Neil Brown ('Baldrige') or Seabird ('Pelican') CTD package.

Analytical. Ammonium and primary amine concentrations were determined by direct injection high performance liquid chromatography (HPLC) (Gardner \& St. John 1991). This method uses a post-column derivitization with $o$-phthaldialdehyde (OPA) and fluorescence detection

Ammonium regeneration. Ammonium regeneration rates were estimated by isotope dilution of ${ }^{15} \mathrm{NH}_{4}$ (Blackburn 1979, Caperon et al. 1979) using a HPLC method that discriminates ${ }^{15} \mathrm{NH}_{4}$ and ${ }^{14} \mathrm{NH}_{4}$ isotopes (Gardner et al. 1991, 1993). In this method, 2 to $4 \mu \mathrm{M}$ ${ }^{15} \mathrm{NH}_{4}$ is added to water samples and changes in the ${ }^{15} \mathrm{NH}_{4}:{ }^{14} \mathrm{NH}_{4}$ ratio are monitored for 2 to $8 \mathrm{~h}$ at ambient temperature. In February, samples were incubated in the dark to minimize $\mathrm{N}$-cycling by autotrophic organisms. Samples taken on the September cruise were incubated in deck incubators at near in situ light levels and temperatures in an attempt to simulate natural conditions (Lohrenz et al. 1990). The ${ }^{15} \mathrm{NH}_{4}$ regeneration and incorporation rates were calculated using the Blackburn-Caperon model (Blackburn 1979, Caperon et al. 1979). Incorporation rates are expressed as 'potential' rates because uptake increases proportional to concentration and ammonium was added at greater than tracer levels. Regeneration should be much less sensitive to ammonium concentrations in the shortterm, however, if phytoplankton production and DON excretion were stimulated by additions of ammonium, regeneration rates may be slightly overestimated (Selmer 1988).

Bacterial abundance and production. Bacterial abundance was estimated with acridine orange staining and epifluorescence microscopy of duplicate sam- ples (Hobbie et al. 1977). Bacterial production was estimated from rates of tritiated thymidine incorporation into DNA (Fuhrman \& Azam 1982). Duplicate samples were incubated with $20 \mathrm{nM}$ (final concentration) of [methyl- ${ }^{3} \mathrm{H}$ ] thymidine (TdR) (Amersham). Nucleic acid and protein fractions were separated with a trichloroacetic acid extraction procedure (Chin-Leo \& Benner 1992). Killed blanks were used to correct for abiotic adsorption to filters. Formalin was added to a final concentration of $4 \% 15$ to $20 \mathrm{~min}$ prior to the addition of radioisotope. Growth rates in summer surface waters were estimated using an empirically determined TdR conversion factor for the Mississippi River plume (Chin-Leo \& Benner 1992) and a cell to carbon conversion factor of $20 \mathrm{fg} \mathrm{C}$ cell $^{-1}$ (Lee \& Fuhrman 1987).

Amino acid turnover rates. Amino acid turnover rates were estimated with a mixture of tritium-labeled amino acids from algal protein hydrolysate (Amersham). Tracer amounts (less than $1 \mathrm{nM}$ final concentration) were added to duplicate samples which were incubated for 3 to $30 \mathrm{~min}$ at ambient temperature Incubations were terminated by filtration onto a $0.2 \mu \mathrm{m}$ pore-size filter (Millipore, GSWP). Duplicate filter and filtrate samples were collected and frozen prior to further analyses. Filters were dissolved with $1 \mathrm{ml}$ ethylacetate before radioassay. Turnover rates were corrected for respired amino acids by evaporating the filtrates to remove tritium-labeled water and reconstituting them in distilled water (Fuhrman 1990). Turnover rates were calculated as the logarithmic change in dissolved isotope with time, corrected for respired isotope and sorption to filters in killed samples. All isotope samples were analyzed by quench corrected liquid scintillation analyses.

Bacterial concentration. To estimate the effect of bacteria on ammonium regeneration processes at various abundances, we concentrated the $1 \mu \mathrm{m}$ pore-size filtrate using tangential-flow filtration and estimated ammonium regeneration rates in duplicate by measuring ${ }^{15} \mathrm{NH}_{4}$ isotope dilution and ammonium concentrations at various bacterial abundances (Gardner et al. $1991,1993)$. Various quantities $(0,5,10,15$ and $20 \mathrm{ml})$ of concentrated particles were diluted with ambient seawater from the site of collection to give a final volume of $70 \mathrm{ml}$. Prior to concentrating particles, seawater was pre-filtered through a nominal $1 \mu \mathrm{m}$ pore-size polysulfone capsule filter (Gelman). Subsequently particles were concentrated in winter by multiple passes through a Gelman Acroflux tangential flow filter (0.2 $\mu \mathrm{m}$ nominal pore size) and a stainless steel reservoir. In summer, the technique was improved by concentrating particles in a re-circulating system with a 50000 molecular-weight-cutoff hollow-fiber filter $(\mathrm{A} / \mathrm{G}$ Technology), a glass reservoir and a peristaltic pump. Ca $30 \%$ of the total bacterial community was lost in 
this procedure. Concentrated particles were then added back to unfiltered seawater at various abundances.

In winter, treatments were incubated at ambient temperature in the dark to minimize autotrophic $\mathrm{N}$ cycling, whereas in summer, treatments were incubated at ambient light and temperature. Ammonium regeneration rates were regressed against bacterial abundance to obtain cell-specific regeneration rates. Ambient bacterial regeneration rates were estimated from the slope of this regression line and ambient bacterial abundances. $T$-tests were performed on regression coefficients to determine statistical significance at $\mathrm{p}=0.05$ (Systat 4.1; Wilkinson 1989).

\section{RESULTS}

We examined total community ammonium regeneration rates in the Mississippi River and plume in shortterm experiments by isotope-dilution techniques (Figs. $1 \& 2$ ). Regeneration rates were an order of magnitude higher at mid-salinities on the September cruise than rates on the February cruise. In September, rates were highest at the mid-salinity region of the plume (Fig. 2)
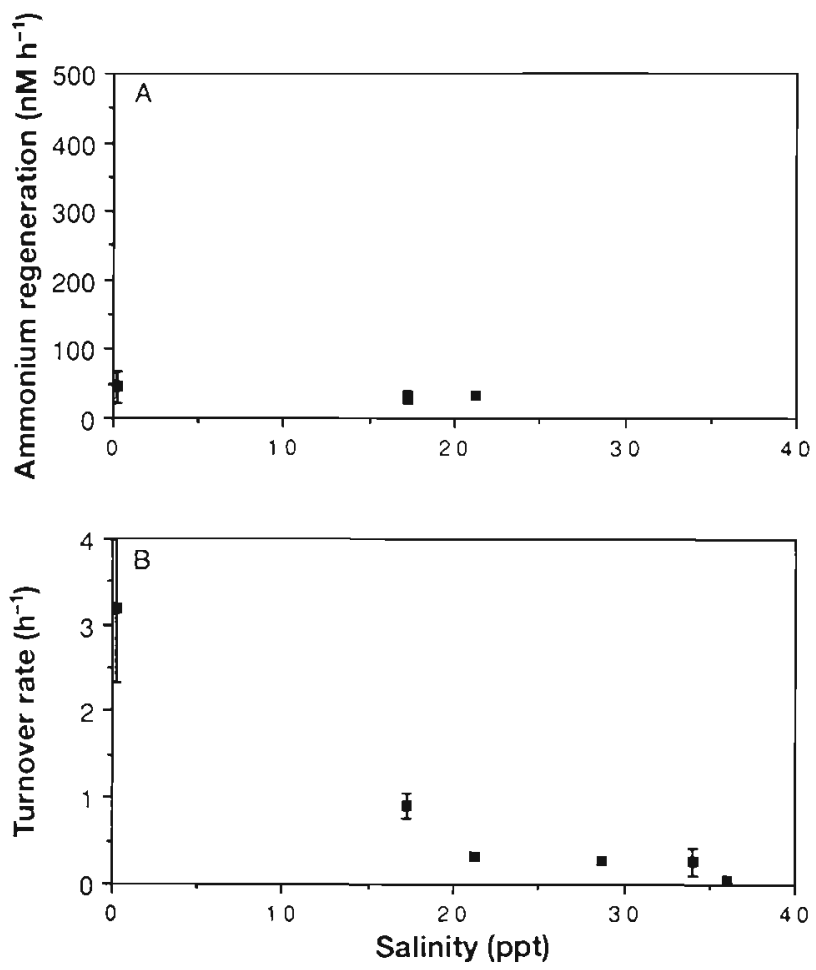

Fig. 1. Ammonium regeneration rates (A) and amino acid turnover rates (B) ( $\pm 1 \mathrm{SE}, \mathrm{n}=2$ ) measured in the Mississippi River plume in February 1991. Regeneration rates were measured with an isotope-dilution method that differentiates ${ }^{15} \mathrm{NH}_{4}$ and ${ }^{14} \mathrm{NH}_{4}$ using a HPLC method
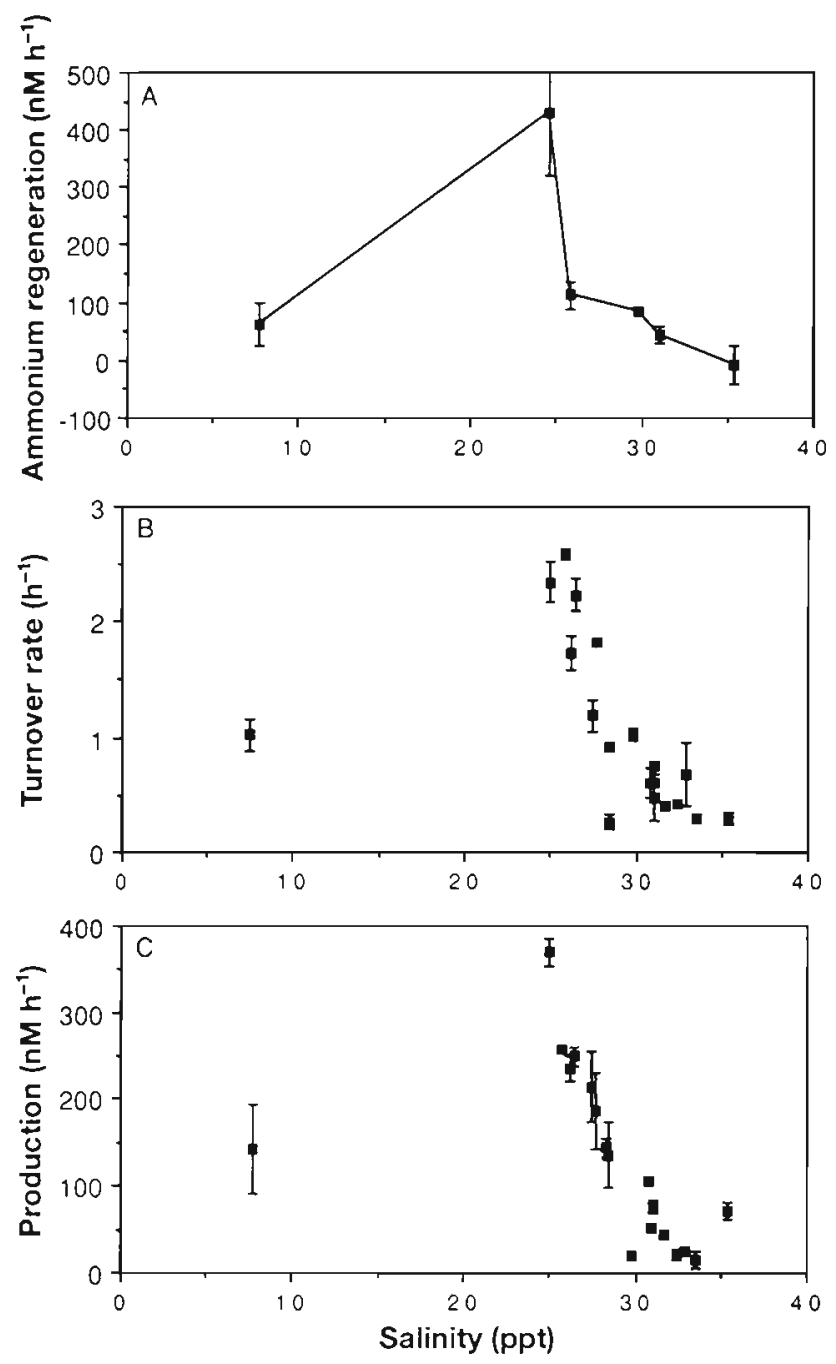

Fig. 2. Ammonium regeneration rates $(A)$, amino acid turnover rates $(B)$ and bacterial production rates $\left(C_{i} n M\right.$ carbon $\left.\mathrm{h}^{-1}\right)( \pm 1 \mathrm{SE}, \mathrm{n}=3$ ) measured in the Mississippi River plume in September 1991. Bacterial production rates were estimated using the tritiated thymidine technique and conversion factors of $1.89 \times 10^{18} \mathrm{cells} \mathrm{mol}^{-1}$ (Chin-Leo \& Benner 1992) and $20 \mathrm{fg} \mathrm{C}$ cell $^{-1}$ (Lee \& Fuhrman 1987)

and in February regeneration rates were low and comparable at all 3 sites where they were measured (Fig. 1).

Bacterial growth rates demonstrated a spatial pattern similar to that of $\mathrm{NH}_{4}$ regeneration rates in summer. Growth rates were high throughout the plume and increased at the mid-salinity region (Fig. 2). Production rates varied from 15 to $370 \mathrm{nM} \mathrm{C} \mathrm{h}^{-1}$ at high and mid-salinities respectively.

The vertical profile of bacterial production was also similar to the vertical profile of ammonium regeneration rates (Fig. 3 of Gardner et al. 1993). Rates at the surface were more than an order of magnitude greater than rates at $35 \mathrm{~m}$. Chin-Leo \& Benner (1992) also 


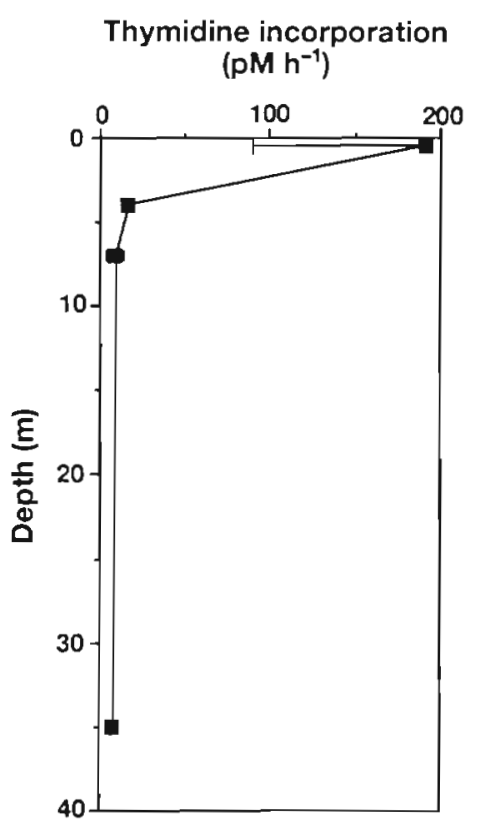

Fig. 3. Vertical profile $( \pm 1 \mathrm{SE}, \mathrm{n}=3$ ) of thymidine incorporation at Site 012 in the Mississippi River plume, September 1991

measured the fastest thymidine incorporation rates at the surface in the Mississippi River plume.

Amino acid turnover rates were of comparable magnitude in winter and summer but the patterns relative to salinity were different (Figs. 1 \& 2). In February, turnover rates were highest in the river and decreased at higher salinities but in September turnover rates were highest at intermediate salinities (Fig. 2), similar to other activity measurements on this cruise. The fastest turnover rate was $2.6 \mathrm{~h}^{-1}$ measured at $25.8 \mathrm{ppt}$ salinity (Fig. 2). Unlike winter results, amino acid turnover rates correlated positively with ammonium regeneration rates across sites in the salinity gradient at sites where both parameters were measured $(r=$ $0.95 ; \mathrm{n}=5$ ).

Vertical profiles of amino acid turnover rates at sites within the plume (Fig. 4) indicate that these compounds were cycled most rapidly in the surface waters, where ammonium regeneration rates (see Gardner et

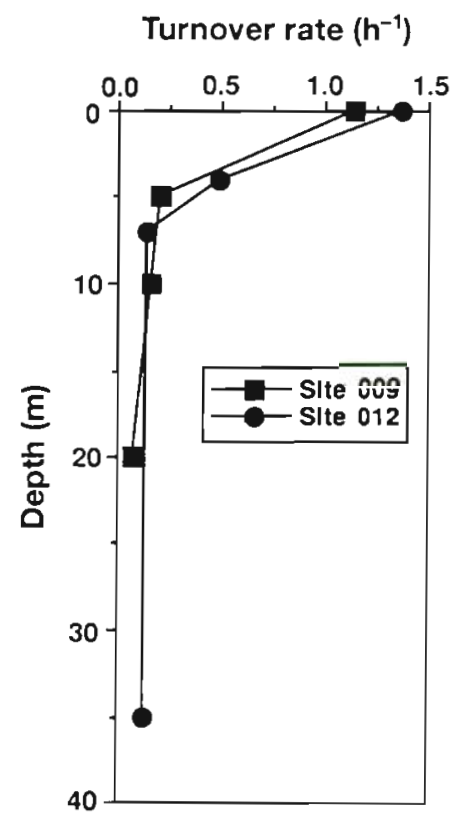

Fig. 4. Vertical profile of amino acid turnover rates at Sites 009 and 012 in the Mississippi River plume, September $1991(\mathrm{n}=3)$ al. 1993) and thymidine uptake rates (Fig. 3) were most rapid, and decreased with depth.

We compared ammonium regeneration rates in whole seawater and pre-filtered seawater $(1 \mu \mathrm{m}$ nominal cut-off) at 3 sites in summer to estimate the importance of bacterial-sized particles in this process (Table 1). Pre-filtration had little effect on regeneration or slightly stimulated regeneration rates at these sites because rates were comparable in pre-filtered and unfiltered treatments (Table 1). There was no evidence that pre-filtering seawater or river water increased ammonium concentrations (Table 1).

The effect of bacterial abundance on ammonium regeneration was studied during both surveys by adding concentrated bacteria back to ambient seawater. Timecourse changes in isotopic ratios for surface water from a mid-plume site with ${ }^{15} \mathrm{NH}_{4}$ and different abundances of added bacteria indicated increasing rates of isotope dilution with increasing bacterial abundances (Fig. 5).

Table 1. Ammonium regeneration rates and ammonium concentrations (with $1 \mathrm{SE}$ ) in whole seawater and filtered (1 $\mu \mathrm{m}$ nominal pore size) seawater at 3 sites in the Mississippi River plume, September $1991(\mathrm{n}=2)$. ND: not detected

\begin{tabular}{|clccc}
\hline Site & Treatment & $\begin{array}{c}\mathrm{NH}_{4} \\
(\mu \mathrm{M})\end{array}$ & $\begin{array}{c}\text { Regeneration rate } \\
\left(\mathrm{nM} \mathrm{h} \mathrm{h}^{-1}\right)\end{array}$ \\
\hline 001 & Filtered & $1.82(0.07)$ & $50(15)$ & 80 \\
028 & Unfiltered & $1.85(0.05)$ & $62(54)$ & 121 \\
& Filtered & $\mathrm{ND}$ & $53(10)$ & 118 \\
& Unfiltered & $\mathrm{ND}$ & $44(20)$ & $93(1.6)$ \\
\end{tabular}


Table 2. Ammonium concentrations for ${ }^{15} \mathrm{NH}_{4}$ experiment Site 012 (surface) with ambient levels of bacteria and $<1 \mu \mathrm{m}$ particle concentrate added at different levels. Samples were taken at $0,1.9$ and $4.0 \mathrm{~h}$ after ${ }^{15} \mathrm{NH}_{4}$ additions. The surface seawater at this station contained $0.6 \mu \mathrm{M}{ }^{15} \mathrm{NH}_{4}$ before sample manipulations. ND: not detected

\begin{tabular}{|cccc|}
\hline $\begin{array}{c}\text { Bacterial abundance } \\
\left.\left(10^{6} \text { cells m }\right)^{-1}\right)\end{array}$ & \multicolumn{3}{c|}{ Ammonium concentrations } \\
$(\mu \mathrm{M})$ & \\
& $0.0 \mathrm{~h}$ & $1.9 \mathrm{~h}$ & $4.0 \mathrm{~h}$ \\
\hline & & 4.38 & 3.83 \\
4.9 & 4.36 & 3.59 & 3.04 \\
35 & 4.10 & 3.14 & 2.02 \\
50 & 4.29 & 2.34 & 0.67 \\
65 & 3.94 & 1.70 & $\mathrm{ND}$ \\
\hline
\end{tabular}

Table 3. Ammonium potential incorporation rates for surface seawater from Site 012 with ambient levels of bacteria and $<1 \mu \mathrm{m}$ particle concentrate added at different levels. Rates were determined from changes in ammonium concentrations and isotope ratios using the Blackburn-Caperon model (Blackburn 1979. Caperon et al. 1979). Rates were determined over a $1.9 \mathrm{~h}$ period after the addition of ${ }^{15} \mathrm{NH}_{4}(\mathrm{n}=2)$

\begin{tabular}{|cc|}
\hline $\begin{array}{c}\text { Bacterial abundance } \\
\left(10^{6} \text { cells } \mathrm{ml}^{-1}\right)\end{array}$ & $\begin{array}{c}\text { Potential incorporation rate } \\
\left(\mu \mathrm{M} \mathrm{h}^{-1}\right)\end{array}$ \\
\hline 4.9 (ambient) & 0.09 \\
20 & 0.63 \\
35 & 1.14 \\
50 & 1.71 \\
65 & 2.42 \\
\hline
\end{tabular}

Ammonium concentrations also decreased progressively as a function of bacterial abundances (Table 2). Ammonium regeneration and incorporation rates both significantly increased in direct proportion to bacterial abundances (Table 3, Fig. 6). There was a strong positive correlation between bacterial abundance and ammonium incorporation $\left(\mathrm{r}^{2}=0.996\right)$. This result clearly indicates that bacterial cells were taking up ammonium and supports the observation that bacteria use ammonium as a nitrogen source at the same time that they are regenerating it from organic nitrogen compounds (Tupas \& Koike 1991). These results demonstrate that differences in natural ammonium regeneration rates, as well as bacterially mediated changes in rates of isotope dilution of ${ }^{15} \mathrm{NH}_{4}$, could be readily distinguished by HPLC in these surface plume samples (Gardner et al. 1993).

At all sites on the summer cruise, plots of regeneration rates versus bacterial abundance resulted in a significant $(p<0.05)$ positive slope (Fig. 6). This result indicates that bacteria were regenerators of ammonium in the plume at this time. Labile DON concentrations were apparently sufficient to support in- creased regeneration rates at increased bacterial abundances.

In contrast, winter regeneration rates at high bacterial abundances approached a limit at the first anchor station (salinity $17 \mathrm{ppt}$ ) and plots produced insignificant slopes $(p=0.05)$ in the river and at the second anchor station (salinity 21 ppt) (Fig. 6). Our ability to concentrate bacteria varied greatly at these 3 sites because of natural variability in ambient bacterial size and biomass, as well as complications arising from high silt loads in the river. Nonetheless, these results imply that, in winter, sufficient dissolved organic nitrogen (DON) substrate was available for ammonium mineralization only at the first anchor station. Apparently, DON concentrations in the river and at the second anchor station could not support a detectable increase in ammonium regeneration and/or bacteria were not regenerators of ammonium at these sites (Fig. 6).

The slopes of the summer regressions (Fig. 6) represent per cell regeneration rates in amol $\left(10^{-18} \mathrm{~mol}\right)$ cell ${ }^{-1} \mathrm{~h}^{-1}$. These results show that bacteria in the river were regenerating the least ammonium per cell of all of the stations and the cells at the highest salinity were regenerating the most ammonium per cell.

Extrapolation of bacterial ammonium regeneration rates to ambient conditions indicated that bacteria regenerated a high proportion of the total community regeneration rate in the mid-salinity region of the plume in summer (Table 4). At Site 012, bacteria regenerated more than $50 \%$ of the total ammonium regeneration. In the river, bacteria regenerated $27 \%$ of the total community rate. The lowest proportion of ammonium regenerated by bacteria was at the highest salinity site ( $7 \%$ at $35 \mathrm{ppt}$ )

Differences in the effects of bacterial abundance on ammonium regeneration in winter and summer may

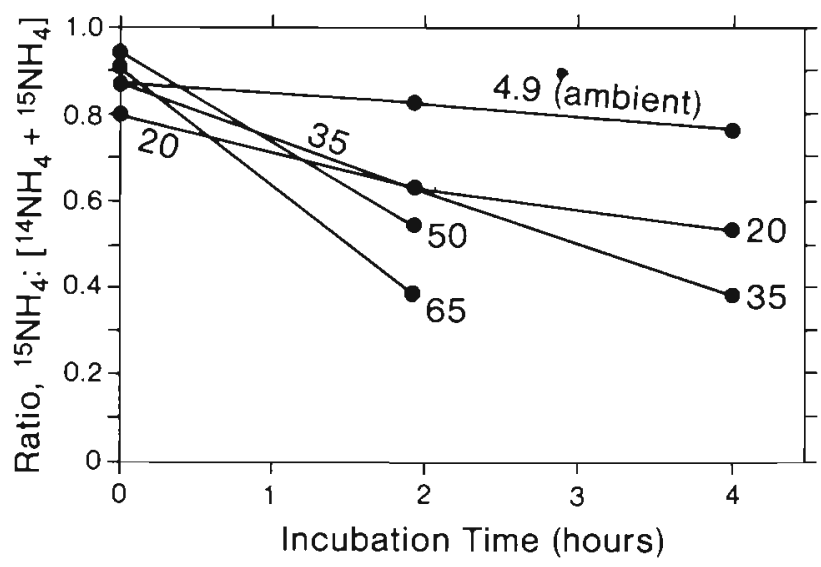

Fig. 5. Time-course of isotope ratios in surface seawater from Site 012 with ambient and increased bacterial abundances $(\mathrm{n}=2$ ). Numbers next to the lines represent bacterial abundances $\left(\times 10^{6} \mathrm{ml}^{-1}\right)$ 

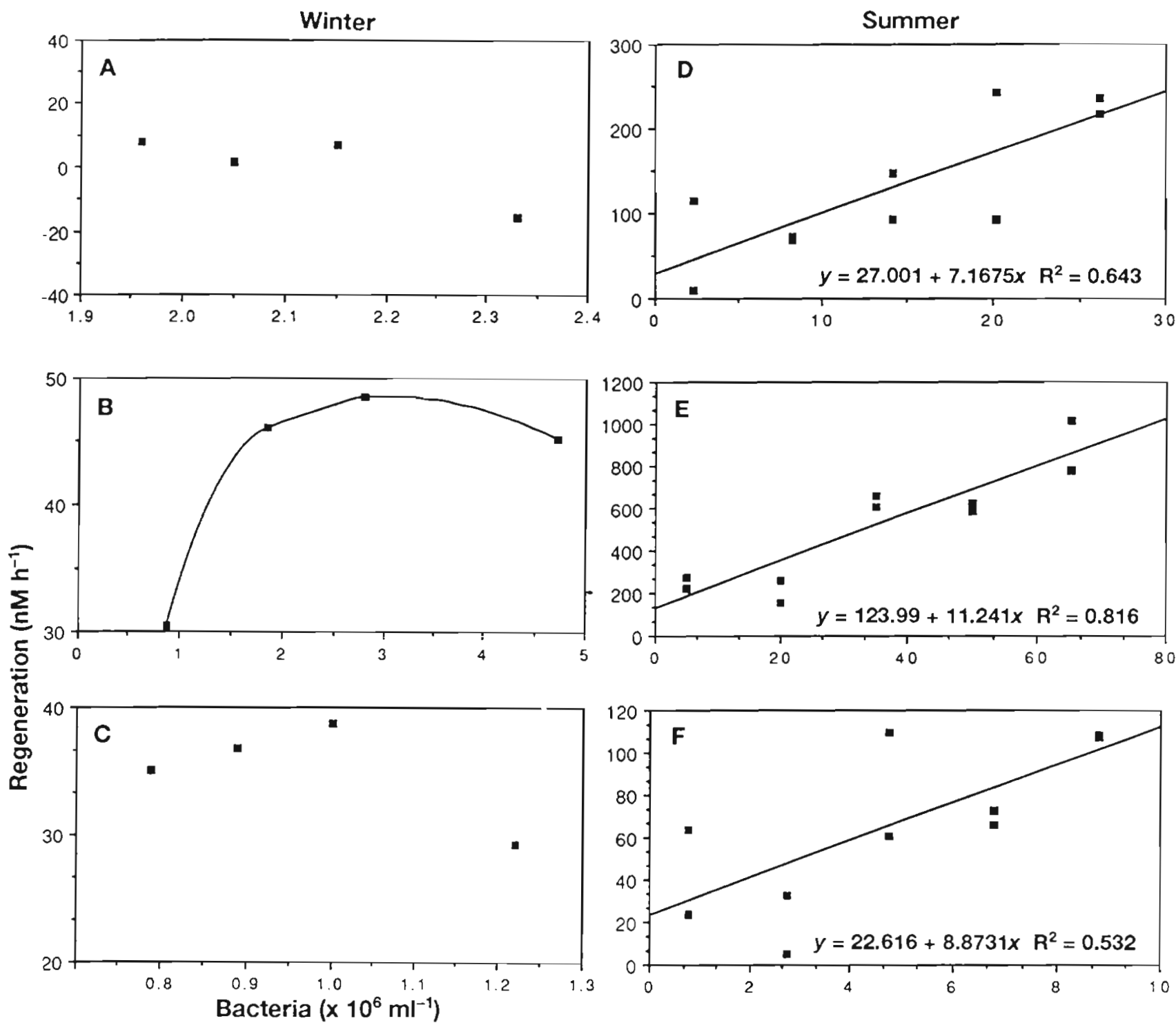

Fig. 6. The effect of increasing bacterial abundance on ammonium regeneration rates in the Mississippi River and plume in February 1991 and September 1991. The effect of bacterial abundance on regeneration rates was estimated at (A) the river station (salinity $0.3 \mathrm{ppt}$ ), (B) the first anchor station (salinity 17.3 ) and (C) the second anchor station (salinity 21.2). In summer, regeneration rates were measured at (D) the river station (salinity $7.6 \mathrm{ppt}$ ), (E) mid-plume (salinity 25.3), (F) Site

028 (salinity 31.0 ) and $(G)$ blue water site (salinity 35.4 )

have been complicated somewhat by differences in our ability to concentrate bacteria on the 2 cruises and by differences in the way samples were incubated. In September, the bacterial abundance was increased by nearly a factor of 30 prior to diluting it back into sea-

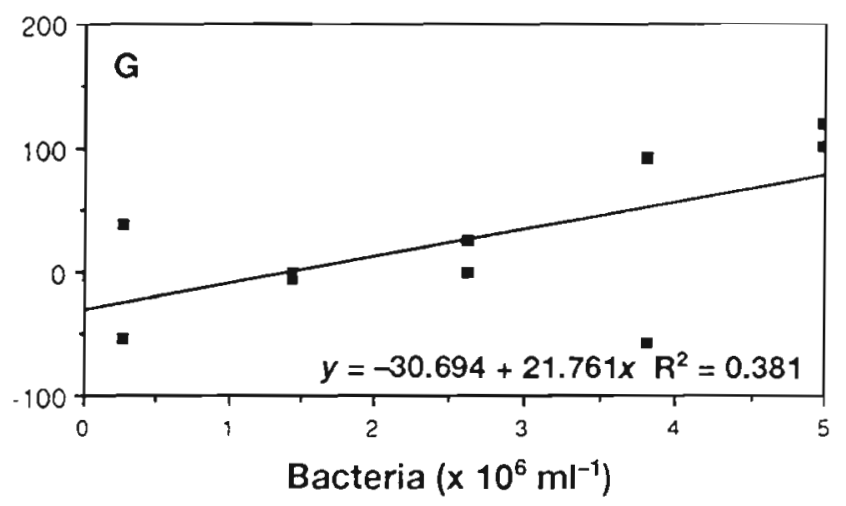

water. In February, the maximum concentration factor for bacterial abundance was only 16. Lower concentrations of added bacteria may have decreased the sensitivity of the analysis at this time. Furthermore, winter samples were incubated in the dark rather than 
Table 4. Ammonium regeneration in the $<1 \mu \mathrm{m}$ size fraction relative to total ammonium regeneration on the September 1991 cruise. The $<1 \mu \mathrm{m}$ size fraction ammonium regeneration rates were estimated by concentrating organisms in this fraction and adding them back to ambient seawater at various concentrations. The regeneration rates were measured using the ${ }^{15} \mathrm{~N}_{-} \mathrm{NH}_{4}$ isotope dilution technique and regressed against bacterial abundance to obtain a per-cell regeneration rate. Ambient rates were estimated by multiplying this rate by the abundance of bacterial cells in surface seawater Rates in the $<1 \mu \mathrm{m}$ pore-size fraction are compared with total regeneration rates to estimate percent regeneration by bacteria. p-values are given for regression of regeneration rates against bacterial abundance. NA: regression not significant at $p=0.05$

\begin{tabular}{|c|c|c|c|c|c|c|}
\hline \multirow[t]{2}{*}{ Cruise } & \multirow[t]{2}{*}{ Site } & \multirow{2}{*}{$\begin{array}{c}\text { Salinity } \\
\text { (ppt) }\end{array}$} & \multicolumn{2}{|c|}{ Ammonium regeneration } & \multirow[t]{2}{*}{ Percent } & \multirow[t]{2}{*}{$\mathrm{p}$} \\
\hline & & & $\begin{array}{c}\text { Total } \\
\left(\mathrm{nM} \mathrm{h}^{-1}\right)\end{array}$ & $\begin{array}{c}<1 \mu \mathrm{m} \\
\left(\mathrm{nM} \mathrm{h} \mathrm{h}^{-1}\right)\end{array}$ & & \\
\hline \multirow{3}{*}{ Feb 1991} & 003 & 17.30 & 31 & NA & NA & 0.081 \\
\hline & 004 & 0.30 & 45 & NA & NA & 0.862 \\
\hline & 006 & 28.30 & 35 & NA & NA & 0.196 \\
\hline \multirow[t]{4}{*}{ Sep 1991} & 001 & 7.64 & 62 & 17 & 27 & 0.005 \\
\hline & 012 & 28.37 & 112 & 56 & 50 & 0.000 \\
\hline & 028 & 30.99 & 44 & 6.7 & 16 & 0.017 \\
\hline & 038 & 35.35 & 86 & 5.7 & 7 & 0.004 \\
\hline
\end{tabular}

under ambient light conditions. Absence of light may have inhibited the production rate of labile DON by phytoplankton in these treatments.

Amino acid turnover rates demonstrated a pattern similar to ammonium regeneration rates when bacterial abundances were manipulated (Fig. 7). In September, increased bacterial abundances resulted in linearly increasing amino acid turnover rates at all sites (Fig. 7). The steepest slope was measured at the midplume site and the shallowest slope was measured in the river.

In February, both ammonium regeneration and amino acid turnover rates seemed to approach a limit at the highest bacterial abundances at all 3 sites (Figs. $6 \& 7$ ). Neither regeneration rates nor amino acid turnover rates increased at high bacterial abundances in the river. In the highest salinity water, ammonium regeneration rates did not increase with bacterial abundance but amino acid turnover rates did increase and were maximized at the highest bacterial abundances used (Figs. 6 \& 7).

\section{DISCUSSION}

\section{Bacterial concentration and addition to ambient seawater}

This study is the first attempt to quantify per cell bacterial nutrient fluxes in situ by manipulating cell abundances. Other researchers have manipulated predator levels to observe the per organism effect on the growth rates of prey (Lehman 1980, Carrick et al. 1991) or nutrient regeneration rates (Glibert et al. 1992). This technique has an advantage over size-fractionation experiments in that bacteria-specific rates can be measured without removing bacterial predators or phytoplankton. Predator removal may result in overestimates of bacterial $\mathrm{N}$-regeneration rates in ${ }^{15} \mathrm{NH}_{4}$ isotope-dilution experiments because of long incubations and changes in trophic interactions (Glibert et al. 1992).

A disadvantage of this technique is that manipulations may alter activities of microbes. Ambient substrates may be depleted in the concentrate because it takes several hours to effectively concentrate microbes. With hollow-fiber systems with faster flow rates, the time required for concentration can be reduced to less than an hour in productive waters. Furthermore, our 50000 molecular-weight-cutoff filter may have concentrated viruses or even high molecular weight organic compounds along with bacteria, and this may confound interpretations of results. We have measured a $250 \mu \mathrm{M}$ (2.5 times ambient concentration) increase in total DOC concentrations using this technique in freshwater samples. However, we detected no increase in primary amines during these manipulations and concentrates were diluted minimally by a factor of 3 with unmanipulated seawater before initiating assays.

A further confounding effect of these treatments is that cells other than bacteria may be concentrated as well. Examination of cell concentrates demonstrated that ca $2 \%$ of the cells were autofluorescing cyanobacteria at the mid-plume site in summer. By concentrating primary producers, the effective organic nitrogen flux into the bacterial pools may have increased. We did not observe abundant cyanobacteria in winter samples or in summer at river and high salinity sites.

Pre-filtration experiments gave higher estimates of bacterial ammonium regeneration rates than bacterial 
Winter
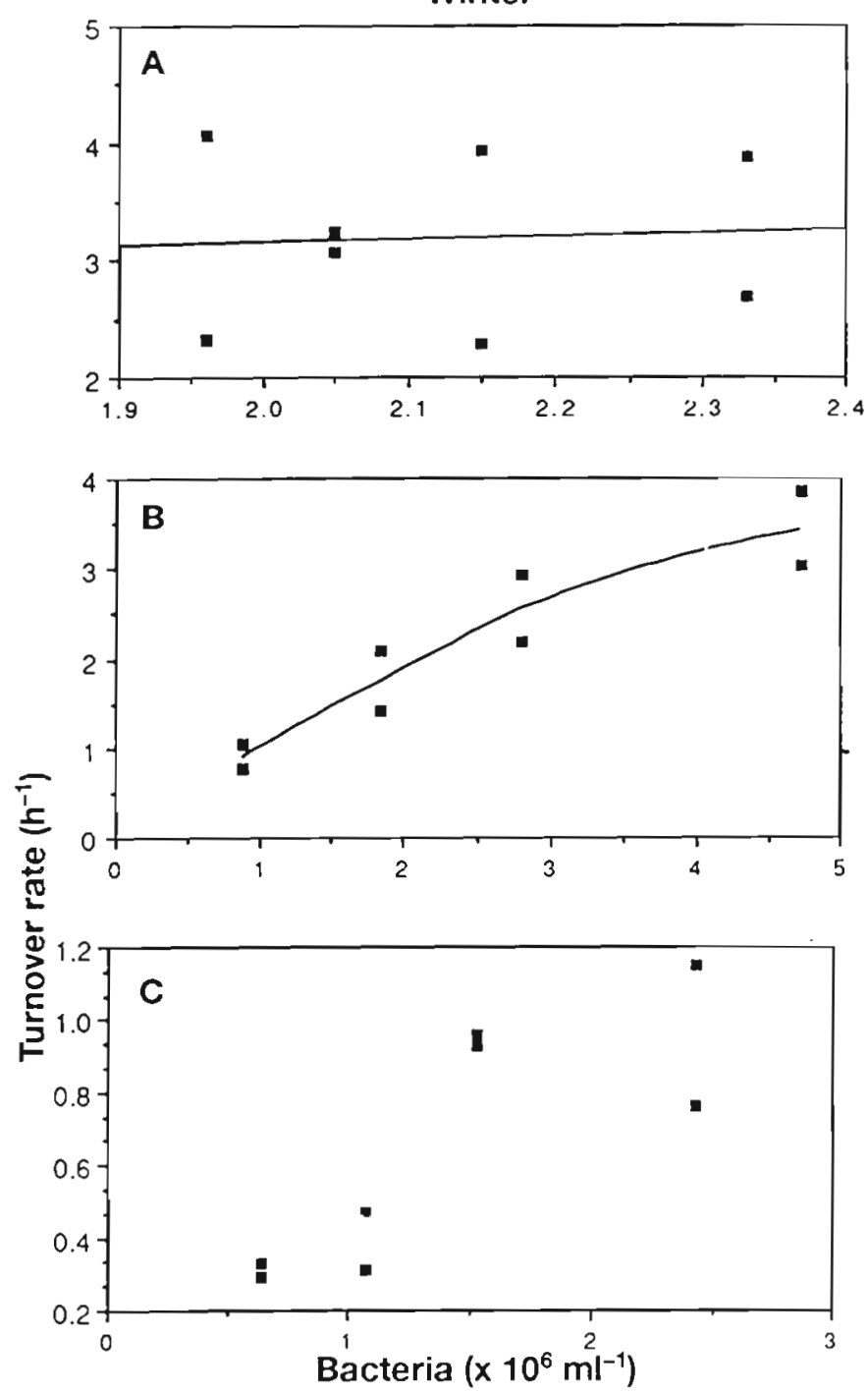

Fig. 7. The effect of increasing bacterial abundance on amino acid turnover rates in the Mississippi River and plume. Sites and salinities as in Fig. 6 except the mid-plume site in summer (E) which was measured at a site with a salinity of $26.5 \mathrm{ppt}$

concentration and addition back into ambient seawater. In the Chesapeake Bay, pre-filtered $(<10 \mu \mathrm{m})$ samples overestimated regeneration rates in whole water or $<202 \mu \mathrm{m}$ size fractions by as much as a factor of 14 (Glibert 1982). Rates may be overestimated in
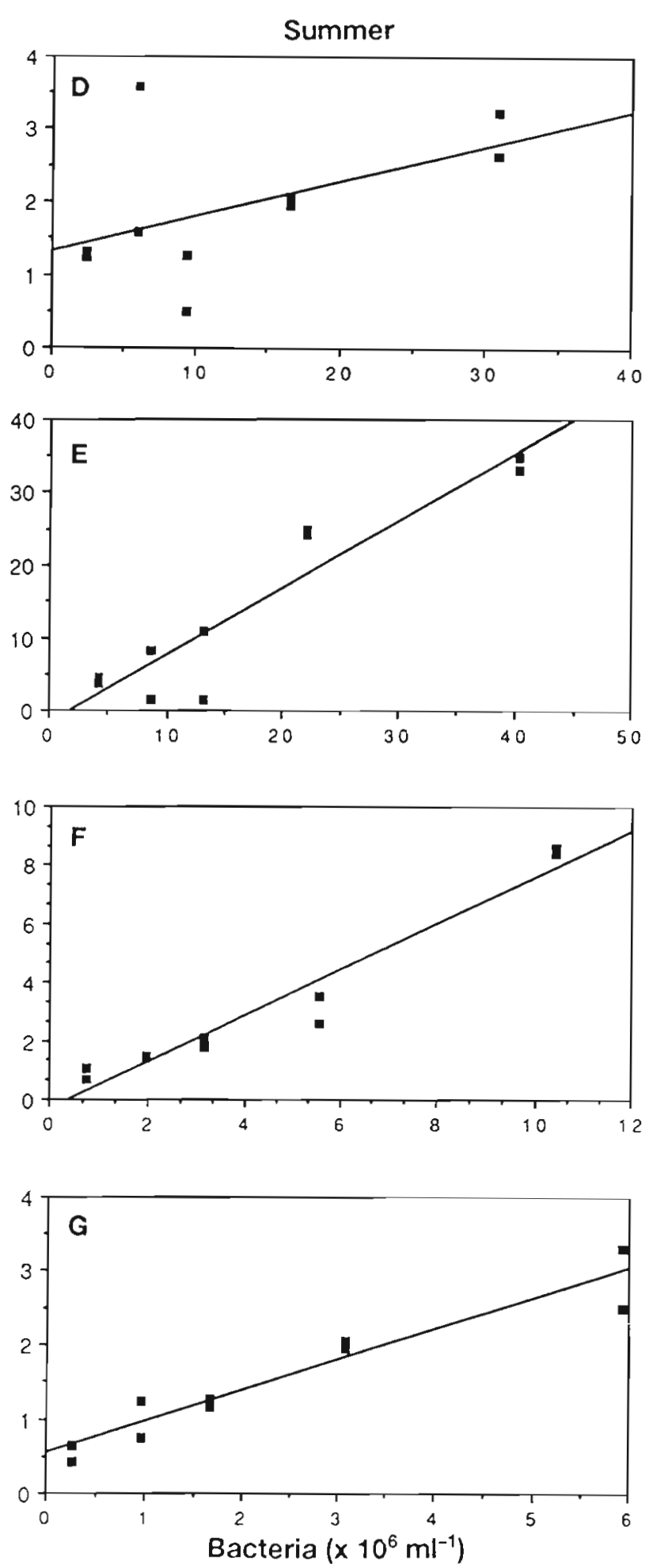

pre-filtration experiments because of the release of DFAA during filtration (Fuhrman \& Bell 1985) or removal of bacterial predators.

In addition to allowing extrapolation of regeneration rates to various bacterial abundances, these plots can 
also provide useful information about labile DON substrates. The slope in linear plots is a useful parameter because it is indicative of the per-cell regeneration rate, which is likely influenced by both the availability and composition of labile DON. Negative slopes would imply that bacteria were consumers of $\mathrm{NH}_{4}$ rather than regenerators. The observation that surface water ammonium regeneration rates increased in direct proportion to the number of added bacteria (Fig. 6) provided evidence that labile organic nitrogen was available at concentrations in excess of ambient bacterial requirements.

The sensitivity of per-cell ammonium regeneration rate determinations is greatly influenced by how effectively bacteria are concentrated from seawater. In summer treatments, a re-circulating system concentrated bacteria from seawater more effectively than multiple passes through a linear flow system used in winter treatments (see $x$-axis scales in Fig. 6). Plots of regeneration rates against bacterial abundances gave significant regressions in summer but not in winter.

\section{Bacterial role in ammonium regeneration}

Our data suggest that bacterial growth and nitrogen regeneration processes are tightly coupled in the Mississippi River plume in summer. Vertical profiles of ammonium regeneration rates (Fig. 3 in Gardner et al. 1993) and thymidine incorporation (Fig. 3) from the mid-salinity region on the September cruise indicated that maximum rates occurred in the surface waters. Furthermore, the maximum dissolved amino acid turnover rates also occurred in the surface waters (Fig. 4). Amino acid turnover rates, ammonium regeneration, and thymidine incorporation all demonstrated similar patterns spatially along the salinity gradient in surface waters. Maximum rates occurred near a salinity of 24 ppt. Other results from the NECOP (Nutrient Enhanced Coastal Ocean Productivityl program also support the view that heterotrophic bacterial production rates were maximal in the surface waters, where the influence of low-salinity river water was greatest (Chin-Leo \& Benner 1992). In another Gulf of Mexico study, amino acid turnover rates were most rapid and bacterial biomass was highest in the photic zone of the neritic region (Ferguson \& Sunda 1984)

Based on experiments where bacteria were concentrated and added back into ambient seawater, bacteria at intermediate salinities regenerate a significant fraction of the total community rate in summer in the Mississippi River plume. Regeneration data indicated that the size-fraction that passed a $1 \mu \mathrm{m}$ pore-size filter (i.e. primarily bacteria) accounted for 7 to $50 \%$ of the regenerated ammonium at this time (Table 4). Size- fractionation of Scripps pier water (California, USA) demonstrated that $40 \%$ of the regeneration activity was by particles $<1 \mu \mathrm{m}$ in diameter (Harrison 1978). In Chesapeake Bay (USA), the bacterial size-fraction regenerated as much as $40 \%$ of the total rate (Glibert 1982), similar to our mid-plume estimates of the heterotrophic bacterial role in ammonium regeneration.

Because bacterial additions did not result in linear increases in regeneration rates, we could not determine the relative importance of bacteria to total community regeneration rates in winter. However, because rates were low, and bacterial regeneration was likely limited by the availability of labile DON, bacterial regeneration was probably a small percent of the total community regeneration rate.

Variation in bacterial ammonium regeneration through the plume in summer may have resulted from differences in the bacterial community size and/or structure, or differences in DON pool size and/or composition. If community structure or DON was the most important factor, then regeneration rates per-cell should have co-varied with the fraction of the total regeneration by bacteria, but this was not the case. Cellspecific regeneration rates were highest at the blue water site but the percent of total community ammonium regeneration attributable to bacteria was highest at the mid-plume site in summer (Table 4). Bacteria accounted for the highest proportion of the community regeneration rate in the mid-plume region where cellspecific regeneration rates were intermediate but bacterial abundances were high.

These results suggest that factors controlling bacterial biomass (i.e. growth rates and predators) may regulate the bacterial contribution to $\mathrm{N}$-regeneration in summer. Flagellates can consume a high proportion of bacterial production in marine waters (Azam et al. 1983, Wikner et al. 1990). Mean daily grazing rates averaged $60 \%$ of bacterial standing stock in 3 different habitats (Wikner et al. 1990). Most plots of ammonium regeneration against bacterial abundance had positive intercepts (Fig. 6) which would imply that organisms larger than bacteria regenerate ammonium, probably, in part, through consumption and digestion of bacteria.

Further support for the importance of bacterioplankton in ammonium regeneration came from estimates of dissolved amino acid turnover rates (Fig. 4). We used bacterial growth rates (Fig. 2), amino acid turnover rates (Fig. 2) and an estimate of heterotrophic bacterial C: $N$ ratios (Bratbak 1985) to estimate the rate of $N$ supply from DFAA relative to the bacterial $\mathrm{N}$ growth requirement. Low and high estimates of amino acid concentrations were used from a study in the Mississippi River plume (2 to $7 \mathrm{nM}$; Ferguson \& Sunda 
1984 ) and the Chesapeake plume (2 to $50 \mathrm{nM}$, assuming 5.3 carbons per amino acid; Fuhrman 1990). At the low extreme of these amino acid concentrations, their fluxes would have provided 0.02 to 0.60 of the bacterial summer nitrogen requirement in the present study, assuming a bacterial biomass $\mathrm{C}: \mathrm{N}$ ratio of 4.75 (Bratbak 1985). At the high extreme (50 nM), amino acid fluxes into bacteria would have provided 15 times the bacterial N-requirement. These calculations clearly indicate that bacteria could facilitate the conversion of amino acid- $\mathrm{N}$ to ammonium, a conclusion that is further supported by our estimates of bacterially mediated ammonium regeneration rates.

Bacterially mediated ammonium regeneration rates in winter were lower than summer rates and did not vary significantly through the plume. Furthermore, although the river site demonstrated a high ammonium regeneration potential based on high amino acid turnover rates and relatively low bacterial growth rates, measured regeneration rates were comparable to those in the plume. These results can be explained by either lower amino acid concentrations in the river relative to the plume or a high nitrogen demand by bacteria growing in the river. Extremely low amino acid concentrations would result in more rapid turnover rates, given comparable bacterial demand for DFAA. High bacterial $\mathrm{N}$ requirements would occur if nitrifying bacteria constituted a significant proportion of the bacterial community in the river because $\mathrm{N}$ is required for both an energy source and incorporation into biomass.

Another possibility for low ammonium regeneration rates is that the microbes were growing on DOC exported from the river with a high $C: N$ ratio. Under these conditions, heterotrophic bacteria regenerate little ammonium (Goldman et al. 1987). There is some evidence that $C: N$ ratios in the DOC pool decrease from the river to the Gulf of Mexico ( $R$. Benner pers. comm.). There is also evidence that DOC in the plume is of marine origin (Benner pers. comm.) and therefore may be more likely to be recently produced by phytoplankton.

\section{DON substrate availability}

The co-occurrence of rapid amino acid turnover rates with rapid ammonium regeneration rates is consistent with the hypothesis that DFAA were important substrates for ammonium regeneration in the plume in summer. A related study (Gardner et al. 1993) also suggested that DFAA could be an important substrate for ammonium regeneration in summer; high concentrations $(4 \mu \mathrm{M})$ of a mixture of ${ }^{15} \mathrm{~N}$-labeled DFAA were consumed in a $24 \mathrm{~h}$ period and 50 to $90 \%$ of the ${ }^{15} \mathrm{~N}$ added as amino acids was recovered as ${ }^{15} \mathrm{~N}$ $\mathrm{NH}_{4}$.

The differences in cell-specific regeneration rates measured in the present study would be strongly influenced by availability of labile DON substrates and the growth efficiency of the bacterial community. High per-cell regeneration rates in blue water relative to the river are likely a consequence of low $\mathrm{C}: \mathrm{N}$ ratios in labile DON, lower growth efficiencies (i.e. nutrient limitation) or some combination of these 2 factors

In winter, DOC:DON substrate availability may regulate $\mathrm{N}$-regeneration rates by heterotrophic bacteria more effectively than losses to predators, because increasing bacterial abundance did not result in linearly increasing ammonium regeneration rates (Fig. 6). In addition to lower DOC:DON production rates in winter that would result from lower phytoplankton production rates, the mean $\mathrm{C}: \mathrm{N}$ ratio of labile substrates may have been higher than in summer, resulting in less efficient N-remineralization by bacteria (Goldman et al. 1987).

On the summer cruise, regeneration rates were highest at the intermediate salinities where amino acid turnover rates were fastest (Fig. 2) and bacterial additions here had the greatest per-cell effect on DFAA turnover rates. These results imply that DFAA may be important substrates for $\mathrm{NH}_{4}$ regeneration in this region. DFAA have a low $C: N$ ratio (mean of about 5 ) relative to other bacterial substrates. Therefore, if they support a significant amount of bacterial metabolism, ammonium regeneration rates should be high.

Regeneration rates increased with bacterial abundances in summer but not in winter, and implied that ambient labile substrates, such as DFAA, were available in excess of bacterial growth requirements in summer. Furthermore, although bacterial growth rates were maximal in mid-plume during winter (Chin-Leo \& Benner 1992), maximum DFAA turnover rates were measured in the river, suggesting that amino acids may not have supported significant growth at this time

Other work supports the view that DFAA supply significant $\mathrm{N}$ for bacterial growth in summer. Only 4 DFAA provided 40 to $130 \%$ of calculated bacterial $\mathrm{N}$-demand in the Chesapeake Bay and these results implied that heterotrophic bacteria are net regenerators of ammonium in this system (Fuhrman 1990). In the subarctic Pacific, DFAA provided $51 \pm 45 \%$ of heterotrophic bacterial N-demand (Keil \& Kirchman 1991). The supply rates of DFAA controlled the excretion rates of ammonium in the subarctic Pacific (Kirchman et al. 1989). DFAA were preferred over $\mathrm{NH}_{4}$ as a $\mathrm{N}$-source, and when DFAA supply rates were adequate, ammonium was regenerated by bacteria. High rates of amino acid turnover correlated positively with ammonium regeneration (Kirchman et al. 1989), similar to results in the present study in summer (Fig. 2). In 
oligotrophic Lake Michigan, ammonium regeneration rates increased when DFAA were added to unfiltered lake water and in the dark, ammonium production rates were approximately equivalent to amino acid re moval rates (Gardner et al. 1987).

We did not examine dissolved combined amino acid fluxes in this study. This pool provided $51 \%$ of bacterial amino- $N$ demand in Chesapeake Bay (Coffin 1989) but was negligible in the subarctic Pacific (Keil \& Kirchman 1991). Dissolved combined amino acids may be important in replenishing dissolved free amino acid pools and some oligopeptides can enter microbial cells without prior hydrolysis (Payne 1976). If a large portion of bacterial $\mathrm{N}$-demand is met through uptake of oligopeptides that do not enter the free amino acid pool in the Mississippi River plume, potential fluxes of regenerated ammonium from bacteria could be even greater than those produced from DFAA fluxes.

\section{Conceptual model}

Determining what organic substrate source(s) are used for microbial production is important to our understanding of heterotrophic bacterial growth. Two likely dissolved organic matter (DOM) sources are DOM exported from the river or DOM excreted by phytoplankton. Regeneration rates, growth rates, and amino acid turnover rates were greatest in mid-plume rather than in the river, where phytoplankton production is low because of turbidity-induced low light levels (Lohrenz et al. 1990). Furthermore, regeneration rates were 5-fold lower in winter than summer when primary productivity is highest. These results imply that phytoplankton may provide labile DON and DOC that heterotrophic bacteria incorporate into biomass or remineralize to inorganic nitrogen and carbon. Chin-Leo $\&$ Benner (1992) estimated that $68 \%$ of the bacterial production in the plume was supported by phytoplankton-derived substrates in summer.

Other studies have identified phytoplankton-produced dissolved free amino acids as an important carbon source to bacterioplankton (Cole 1982, Carlucci et al. 1984, Jørgensen 1987). In a survey of marine and freshwater literature (Cole et al. 1988), bacterial production was significantly correlated with primary production in the photic zones of lakes and the ocean. Furthermore, rates of extracellular release of dissolved organic carbon (DOC) increased linearly with productivity in the coastal marine and estuarine environments (Baines \& Pace 1991).

Loading of ammonium and nitrate from the river are important factors stimulating primary production in the plume, but much of that productivity is maintained by ammonium regeneration once $\mathrm{NH}_{4}$ and $\mathrm{NO}_{3}$, loaded from the river, are taken up. The integrated ammonium regeneration rate at Site 012 on the September cruise was $26.4 \mathrm{mmol} \mathrm{N} \mathrm{m}^{-2} \mathrm{~d}^{-1}$. Using a preliminary estimate of primary productivity at this site (Lohrenz, Fahnenstiel \& Lang unpubl.), and assuming that regenerative processes were the most important source of inorganic nitrogen substrates to phytoplankton, we calculate a $C: N$ ratio less than 1 which is well below the Redfield ratio of 5.6. Regenerative processes are probably the predominant source of inorganic nitrogen at this site because the initial load of inorganic $\mathrm{N}$ would have already been removed from surface waters (surface $\mathrm{NO}_{3}+\mathrm{NO}_{2}$ concentration was ca $0.1 \mu \mathrm{M}$ ). This ratio implies that microbes may be regenerating $\mathrm{N}$ at rates greater than that required by phytoplankton at this site and that significant quantities of ammonium may be transported down-plume and stimulate production elsewhere. Studies in coastal (Harrison 1978) and oligotrophic (Glibert 1982) marine waters indicate that regeneration rates and primary productivity are tightly coupled in surface waters. However, in coastal Georgia waters, $\mathrm{NH}_{4}$ regeneration exceeded phytoplankton N-demand by 1.6 to 2.3 times in surface waters (Hanson et al. 1990). River plumes likely behave differently than autochthonously driven systems because of high loading rates of inorganic and organic nutrients.

We suggest that bacterial N-regeneration through the plume is regulated by biotic interactions under the constraints imposed by the physical system. In the river and near-shore plume, the potential for bacterial $\mathrm{N}$ regeneration is high because of high bacterial abundance but labile $\mathrm{C}: \mathrm{N}$ ratios are high and phytoplankton production rates are low because of light limitation (Lohrenz et al. 1990). Consequently regeneration rates are low (Fig. 8).

In the mid-plume region, bacterial abundances and growth rates are high. In addition, phytoplankton production and biomass are high which results in high labile DON availability and low labile $C: N$ ratios. Consequently, a high proportion of the organic $\mathrm{N}$ in phytoplankton passes from phytoplankton to the dissolved organic $\mathrm{N}$ pool and is regenerated by bacteria (Fig. 8). Although bacterial predators consume a significant amount of bacterial production in the midplume region, bacterial growth rates are high and $\mathrm{C}: \mathrm{N}$ ratios are low, and bacteria mediate a significant flux of DON to ammonium.

In the high-salinity waters, phytoplankton production, and consequently, bacterial production decrease. Carbon to nitrogen ratios of labile DON remain low because most organic matter is produced by phytoplankton. However, concentrations of available substrate are low, bacterial growth rates are low and a high proportion of production is consumed by bacterial grazers. 


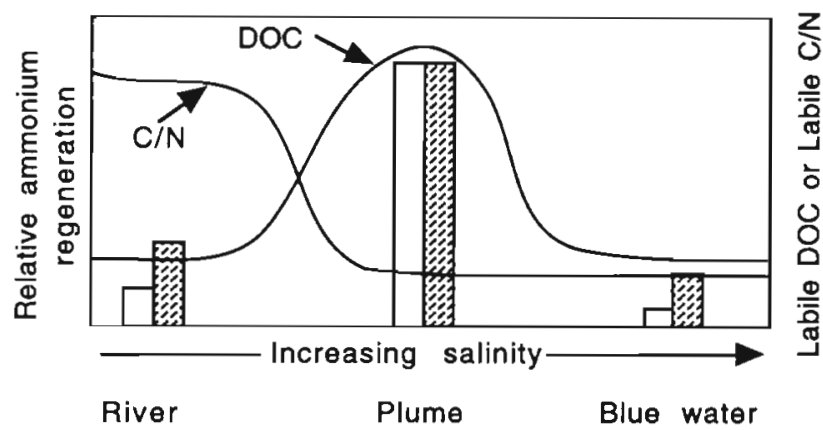

Fig. 8. Hypothesized relationships among ammonium regeneration rates, dissolved labile DOC, and dissolved labile $\mathrm{C} / \mathrm{N}$ ratios. Open bars: ammonium regeneration rates in heterotrophic bacteria; hatched bars: ammonium regeneration rates by other organisms

Consequently, the majority of the ammonium regeneration is mediated by particle consumption with predator excretion (Fig. 8).

Similar processes regulate ammonium regeneration in winter and summer. However, because phytoplankton production is lowest in winter, labile DON availability is low and decreases the significance of $\mathrm{N}$-regeneration to primary production and also decreases the range of regeneration rates observed through the plume.

Acknowledgements. This work was supported by the National Oceanic and Atmospheric Administration through the Coastal Ocean Program Office. We thank the crews of the 'Malcolm Baldrige' and 'Pelican' for sampling assistance. Greg Lang provided primary productivity data and assisted with figures. Steve Lohrenz provided on-deck incubators. Ron Benner, Bob Heath, Rick Keil and 2 anonymous reviewers graciously reviewed a previous version of this manuscript. This paper is GLERL contribution number 794 .

\section{LITERATURE CITED}

Azam, F., Fenchel, T., Field, J. G., Gray, J. S., Meyer-Reil, L. A., Thingstad, F. (1983). The ecological role of watercolumn microbes in the sea. Mar. Ecol. Prog. Ser. 10: $257-263$

Baines, S. B., Pace, M. L. (1991). The production of dissolved organic matter by phytoplankton and its importance to bacteria: patterns across marine and freshwater systems. Limnol. Oceanogr. 36: 1078-1090

Blackburn, H. T (1979). Method for measuring rates of $\mathrm{NH}_{4}{ }^{+}$ turnover in anoxic marine sediments, using a ${ }^{15} \mathrm{~N}-\mathrm{NH}_{4}{ }^{+}$ dilution technique. Appl environ. Microbiol. 37: 760-765

Bratbak, G. (1985). Bacterial biovolume and biomass estimations. Appl. environ. Microbiol. 49: 1488-1493

Caperon, J., Schell, D., Hirota, J., Laws, E. (1979). Ammonium excretion rates in Kanoeke Bay, Hawaii, measured by a ${ }^{15} \mathrm{~N}$ isotope dilution technique. Mar. Bjol. 54: 33-40

Carlucci, A. F., Craven, D. B., Henrichs, S. M. (1984). Diel production and microheterotrophic utilization of dissolved free amino acids in waters off Southern California. Appl. environ. Microbiol. 48: 165-170
Carrick, H. J., Fahnenstiel, G. L., Stoermer, E. F., Wetzel, R. G. (1991). The importance of zooplankton-protozoan trophic couplings in Lake Michigan. Limnol. Oceanogr. 36: $1335-1345$

Chin-Leo, G., Benner, R. (1992). Enhanced bacterioplankton production and respiration at intermediate salinities in the Mississippi River plume. Mar. Ecol. Prog. Ser. 87: 87-103

Coffin, R. B. (1989). Bacterial uptake of dissolved free and combined amino acids in estuarine waters. Limnol. Oceanogr. 34: 531-542

Cole, J. C., Findlay, S., Pace, M. L. (1988). Bacterial production in fresh and saltwater ecosystems: a cross-system overview. Mar. Ecol. Prog. Ser. 43: 1-10

Cole, J. J. (1982). Interactions between bacteria and algae in aquatic ecosystems. A. Rev. Ecol. Syst. 13: 291-314

Ducklow, H. W. (1983). Production and fate of bacteria in the oceans. BioSci. 33: 494-501

Ferguson, R. L., Sunda, W. G. (1984). Utilization of amino acids by planktonic marine bacteria: importance of clean technique and low substrate additions. Limnol. Oceanogr. 29: $258-274$

Fuhrman, J. A. (1990). Dissolved free amino acid cycling in an estuarine outflow plume. Mar. Ecol. Prog. Ser. 66: $197-203$

Fuhrman, J. A., Azam, F. (1982). Thymidine incorporation as a measure of heterotrophic bacterioplankton production in marine surface waters: evaluation and field results. Mar. Biol. 66: 109-120

Fuhrman, J. A., Bell, T. M. (1985). Biological considerations in the measurement of dissolved free amino acids in seawater and implications for chemical and microbiological studies. Mar. Ecol. Prog. Ser. 25: 13-21

Gardner, W. S., Chandler, J. F., Laird, G. A., Carrick, H. J (1987). Sources and fate of dissolved free amino acids in epilimnetic Lake Michigan water. Limnol. Oceanogr. 32: $1353-1362$

Gardner, W. S., Cotner, J. B. Jr, Herche, L. R. (1993) Chromatographic measurement of nitrogen mineralization rates in marine coastal waters with ${ }^{15} \mathrm{~N}$. Mar. Ecol. Prog. Ser. 93: 65-73

Gardner, W. S., Herche, L. R., St. John, P. A., Seitzinger, S. P. (1991). High performance liquid chromatographic determination of ${ }^{15} \mathrm{NH}_{4}:\left[{ }^{14} \mathrm{NH}_{4}+{ }^{15} \mathrm{NH}_{4}\right]$ ion ratios in seawater for isotope dilution experiments. Anal. Chem. 63: $1838-1843$

Gardner, W. S., St. John, P. A. (1991). High-performance liquid chromatographic method to determine ammonium ion and primary amines in seawater. Anal. Chem. 63: 537-540

Glibert, P. M. (1982). Regional studies of daily, seasonal and size fraction variability in ammonium remineralization. Mar. Biol. 70: 209-222

Glibert, P. M., Miller, C. A., Garside, C., Roman, M. R., McManus, G. B. (1992). $\mathrm{NH}_{4}{ }^{+}$regeneration and grazing interdependent processes in size-fractionated ${ }^{15} \mathrm{NH}_{4}{ }^{+}$experiments. Mar. Ecol. Progr. Ser. 82: 65-74

Goldman, J. C., Caron, D. A., Dennett, M. R. (1987). Regulation of gross growth efficiency and ammonium regeneration in bacteria by substrate C: $N$ ratio. Limnol. Oceanogr 32: $1239-1252$

Hanson, R. B., Robertson, C. Y., Yoder, J. A., Verity, P. G. Bishop, S. S. (1990). Nitrogen recycling in coastal waters of southeastern U.S. during summer 1986. J. mar. Res. 48 $641-660$

Harrison, W. G. (1978). Experimental measurements of nitrogen remineralization in coastal waters. Limnol. Oceanogr. 23: $684-694$

Hobbie, J. E., Daley, R. J., Jasper, S. (1977). Use of Nuclepore 
filters for counting bacteria by fluorescence microscopy Appl. environ. Microbiol. 33: 1225-1228

Jørgensen, N. O. G. (1987). Free amino acids in lakes: concentrations and assimilation rates in relation to phytoplankton and bacterial production. Limnol. Oceanogr. 32 97-111

Jørgensen, N. O. G., Sondergaard, M. (1984). Are dissolved free amino acids free? Microb. Ecol 10: 301-316

Keil, R. G., Kirchman, D. L. (1991). Contribution of dissolved free amino acids and ammonium to the nitrogen requirements of heterotrophic bacterioplankton. Mar. Ecol. Prog. Ser. 73: $1-10$

Kirchman, D. L., Keil, R. G., Wheeler, P. A. (1989). The effect of amino acids on ammonium utilization and regeneration by heterotrophic bacteria in the subarctic Pacific. Deep Sea Res. 36: 1763-1776

Lee, S., Fuhrman, J. A. (1987). Relationships between biovolume and biomass of naturally derived marine bacterioplankton. Appl. environ. Microbiol. 53: 1298-1303

Lehman, J. T. (1980). Release and cycling of nutrients

This article was presented by B. \& E. Sherr, Corvallis,

Oregon, USA between planktonic algae and herbivores. Limnol. Oceanogr. 25: 620-632

Lohrenz, S. E., Dagg, M. J., Whitledge, T. E. (1990). Enhanced primary production at the plume/oceanic interface of the Mississippi River. Cont. Shelf Res. 10: 639-664

Payne, J. W. (1976). Peptides and microorganisms. Adv. microb. Physiol. 13: 55-113

Selmer, J.-S. (1988). Ammonium regeneration in eutrophicated coastal waters of Sweden. Mar. Ecol. Prog. Ser. 44 $265-273$

Tupas, L., Koike, I. (1991). Simultaneous uptake and regeneration of ammonium by mixed assembalges of heterotrophic marine bacteria. Mar. Ecol. Prog. Ser. 70: 273-282

Turner, R. E., Rabalais, N. N. (1991). Changes in Mississippi River water quality this century. BioSci. 41: 140-147

Wikner, J., Rassoulzadegan, F., Hagstrom, A. (1990). Periodic bacterivore activity balances bacterial growth in the marine environment. Limnol. Oceanogr. 35: 313- 324

Wilkinson, L. (1989). SYSTAT: the system for statistics. Systat, Inc., Evanston, IL

Manuscript first received: July 17, 1992

Revised version accepted: December 7, 1992 